\title{
Vodna imena na doberdobskem Krasu
}

\author{
Vlado Klemše (Gorica)
}

IZVLEČEK: V članku obravnava avtor vodna imena Doberdobskega, Prelosnega in Sabeljskega jezera ter Močil, navaja dosedanje ugotovitve in razlage imen ter opozarja na značilne hidronime, kot so Črepola/Črepolo, P'č, Počka, Rebok, Rošta, Roja in Pivka.

ABSTRACT: This articles discusses the hydronyms associated with Lake Doberdo, Lake Pietrarossa, the Sablici Marsh, and the Mucille Lakes, presents findings and explanations of the names to date, and draws attention to typical hydronyms such as Črepola/Črepolo, $P$ '̌́, Počka, Rebok, Rošta, Roja, and Pivka.

Kamen je razpoznavni znak Krasa, voda pa element, ki omogoča življenje in preživetje v pokrajini, ki je v prejšnjih stoletjih kazala drugačno, zagotovo manj prijazno podobo. Voda v najbolj naravni obliki, kot dež, voda, ki se zbira v škavencah, v umetno narejenih zbiralnikih, štirnah, voda v obliki občasnih tokav, potokov, žlebov in strug, kalov in luž. Pa tudi voda v kraških jamah, kamor odteka skozi požerljuhe, živa voda presihajočih jezer, ki so značilnost doberdobskega Krasa, območja med Timavo in Vipavo ter med Dolom in Furlansko ravnino oziroma Laškim.

Poleg Doberdobskega jezera, ki je po površini največje in najbolj znano, so na tem območju še Prelosno in Sabeljsko jezero, Močila in vrsta drugih manj izrazitih kraških pojavov, vezanih na vodo. K temu velja dodati še močvirnat svet med Štivanom in Tržičem, imenovan Ližerc (it. Lisert). Za to območje se občasno uporablja tudi ime Laško jezero, vendar gre za netočnost oziroma za zamenjavo, zelo verjetno sad nepoznavanja zgodovinskih okoliščin in velikih sprememb, posledic posegov v prostor z gradnjo prometnih infrastruktur (železnica, ceste, daljnovodi, melioracije), ki so ta prostor povsem preoblikovale, začenši od druge polovice 18 . stoletja. Podobno razmišljanje, glede lokacije namreč, velja za hidronim, reko oziroma kanal Lokóvec/Lokávac (it. Locovaz).

$\mathrm{V}$ prostoru med Vipavo in Timavo ter med Dolom in Laškim je več vasi in zaselkov: Jamlje, Dol s svojimi zaselki, Doberdob s Poljanami, Medja vas, Vrh in Martinščina. Na obrobju pa so Štivan, Gabrje, Rupa, Peč in Miren. Na severozahodu so še Rubije, Petovlje, Zdravščine in Zagraj.

Geografski oris je podatek, ki ga ni mogoče zaobiti ob preučevanju krajevne- 
ga imenoslovja, posebej v prostoru, ki je stoletja stičišče slovanskega/slovenskega in romanskega sveta.

Prav tako ni mogoče mimo zgodovinskega dejstva, da je prav skozi ta prostor, od Zagraja, po zadnjih obronkih Krasa do prvih vzpetin nad Tržičem (it. Monfalcone), dolgo potekala državna meja med Beneško republiko in avstrijskimi deželami in se ohranila do leta 1797. Značilnost tega prostora je tudi stoletja dolgo sobivanje po izvoru romanske, šmartinske (Martinščina) skupnosti s slovensko okolico, kar se seveda odraža tudi v toponomastiki. Pogosti so primeri dvojnega poimenovanja (polimorfna imena), kakor tudi prisotnost slovenskih toponimov na območju Martinščine, Zagraja, Petovelj in tudi drugih krajev in seveda tudi obratno. Značilen primer polimorfnega imena je toponim Razkriž/Crosera (cestno križišče na meji med katastrskimi občinami Doberdob, Zagraj in Martinščina). Najvišja točka doberdobskega Krasa je Debela griža $(275 \mathrm{~m})$. Ime uporabljajo prebivalci slovenskih vasi, medtem ko je za Šmartince gora od nekdaj samo Cimòn, kar po slovensko pomeni Veliki vrh. Hidronim Fontane/Fontana, kar po pomenu ustreza štirnam, štirni oziroma štirnci, je zabeležen na območju Martinščine, vendar se je ime ukoreninilo tudi v nekaj kilometrov oddaljenem Opatjem selu (bolj pravilna in utemeljena bi bila množinska raba imena - Opatja sela; ljudsko Pačjasela) in tudi v nekaterih drugih krajih matičnega Krasa. Podobna ugotovitev velja za splošno razširjeni hidronim Potok. Ime je pogosto na teritoriju Petovelj, Zdravščin, Zagraja in deloma Foljana. Rošta, roja in rebok so izposojenke iz furlanščine, ki pa so se razširile daleč v notranjost slovenskega etničnega prostora na Primorskem.

Značilen hidronim je Črepola/Črepolo v spodnjem toku Vipave. Verjetno novejšega izvora sta hidronima $P^{\prime c}$ s pomenom »vodnjak s talno, izvirno vodo«, in Počka, s pomenom »manjši vodni vir, studenec«. V seznam značilnih vodnih imen tega območja bi lahko uvrstili hidronim Pivka/Piuka (navedba v Franciscejskem katastru).

Nekaj nemških ali domnevno iz nemščine izvedenih imen je zaslediti predvsem v arhivskem gradivu, npr. mikrotoponim Regališče na območju med Dolom in Opatjim selom, dalje mikrotoponim Kuglišče/Kulišče na območju Vrha, hidronima Bajer pri Rupi ter Mautte, potok, ki razmejuje občini Sovodnje ob Soči/Savogna d'Isonzo in Zagraj/Sagrado. Tudi oronim Varda nad Boneti in Jamljami bi po vsej verjetnosti sodil $\mathrm{v}$ to skupino imen.

Še zmeraj močno opazne so sledi, ki jih je tudi na področju toponomastike zapustila prva svetovna vojna. Doberdobski Kras je bil med najbolj krvavimi prizorišči nesmiselnega in tragičnega početja. Številni žegni, jarki, špitali, kaverne in komande nosijo v sebi sporočilnost o dogajanju in dogodkih, ki so še zmeraj globoko zasidrani v kolektivnem spominu prebivalstva, čeprav so se dogodili pred devetdesetimi leti.

Morda se bodo, poleg zbirateljev materialnih ostankov prve svetovne vojne, našli tudi zbiralci in zapisovalci dediščine, ki je sicer manj otipljiva kakor staro orožje, topovske granate, vojaška oprema, vendar s prav tako močno sporočilnostjo. Vendar to je drugo, novo poglavje. Danes bi spregovorili o vodnih imenih na doberdobskem Krasu, vsaj o nekaterih. 
ČRÉPOLA/ČRÉPULA, f. s., mtn in hdn na Vipavi, na območju Rupe, Peči, Gabrij in Rubij. Označuje kraj v rečni strugi, do koder je bila speljana pot oziroma je imela živina lahek dostop. Na črepoli se je napajala živina, ob suši pa so krajani in tudi prebivalci kraških vasi zajemali vodo za kuhanje in druge potrebe. Še po drugi svetovni vojni so v sušnem obdobju $\mathrm{Na}$ črepoli zajemali in vozili vodo v lesenih lodricah, posebnih, na vozovih nameščenih sodih. V krajevnem govoru je črepola ženskega spola, kar potrjuje tudi mestniška oblika Na črepoli. Znana je tudi starejša oblika, Serepalo (mapa Franciscejskega katastra, 1818, za Rubije). V Terezijanskem katastru za Miren sta zabeleženi imeni Na chirepolo in Chirepola. Črepola pri Rupi se prekriva z mikrotoponimom Brod, $\mathrm{Na}$ Brodu.

SABELJSKO JEZERO, n. s., hdn na meji med občinama Doberdob/Doberdò del Lago in Tržič/Monfalcone. Močvirnato območje, ki je bilo po številnih posegih, zlasti ob gradnji avtocestnega vozlišča, povsem spremenjeno. Prve navedbe so iz 13. stoletja: Gesira je nedvomno slov. jezero (TEA). To potrjuje tudi domnevo, da je današnje sestavljeno ime, Sabeljsko jezero, nastalo kasneje. Številne so navedbe iz 17., 18. in 19. stoletja, zlasti iz Franciscejskega katastra (Sablicz, Sablitz). Jožefinski vojaški zemljevid (1763-1787) navaja potok Sabliz, nekoliko niže, v smeri proti morju, pa Palustine.

Navedba (PSCC, 174) iz 18. stoletja govori, da je hišo na mestu z imenom Sabliza zgradil devinski grof.

Nad (nekdanjim) jezerom je zaselek Sabliči, m. pl. Danes šteje šest hiš, ki so na območju katastrske občine Jamlje, upravno pa sodijo v občino Doberdob.

Raba krajevnega imena Sabliči (v predložni rabi pri Sabličih, od Sabličev, etnik ni znan) opozarja, da je ime zaselka verjetno izvedeno iz osebnega imena ali priimka, podobno kot so iz imen oziroma priimkov izvedena imena zaselkov v Dolu (Boneti, Ferletiči, Vižintini, Devetaki, Mikoli, Palki, v novejšem času se za slednje vse bolj dosledno uporablja ime Palkišče). Milko Kos navaja (Srednjeveški urbarji za Slovenijo III, str. 167, 168) nekega Saubkizha, Saukhicza, Saukicza v Števerjanu, okrog leta 1523.

Glede pomena imena bi veljalo upoštevati še drugo možnost, da je ime nastalo po značilnosti kraja oziroma območja. Mokrišča so idealno naravno okolje za žabe. Žabč, Žabnic, Žabelj in podobnih imen pa je veliko v slovenskem prostoru.

Manj verjetna se zdi razlaga, po kateri naj bi se v imenu Sabeljsko (jezero) skrivala romanska beseda sabulum s pomenom »pesek«, kar omenja France Bezlaj v knjigi Slovenska vodna imena II. Dvomi se porajajo zlasti ob upoštevanju geomorfoloških značilnosti kraja. Vode v presihajočih kraških jezerih običajno ne odlagajo peska. Isti avtor uporablja ime Sabliško jezero, krajani pa pravijo Sabeljsko jezero, kar se mi zdi bolj pravilno.

Na ožjem območju Sabeljskega jezera so še trije hidronimi: Studenci, Vrba in Puščjetka. Na obrobju najdemo še Žleb, Krč in Pološko.

MOČILA/MUCILLE, n. pl., hdn v občini Ronke/Ronchi dei Legionari označuje kraški izvir, manjše presihajoče jezero. Območje je izgubilo prvobitno podobo zaradi gradbenih in drugih posegov (avtocesta, stanovanjske hiše, konjerejska farma itd)

Ime Muzilas se prvič omenja leta 1382 (Domini 1998) in kasneje Mocille (1741). 
$4 \quad$ V Franciscejskem katastru katastrske občine Romjan/Vermegliano, Mocille. V istem viru je omenjen tudi potok roja Mocille, ki je povezoval različne kraške izvire. Ime se je ohranilo tudi v uradni toponomastiki današnje občine Ronke/Ronchi dei Legionari (ulica Mucille). Dva izvira presihajočega jezera sta v bizjaškem narečju evidentirana kot Gorgo in Gorghet (gorghet je pomanjševalnica za gorgo; Puntin).

PRELOSNO/PRELAZNO JEZERO, n. s., bizjaško Lago di Pierarossa, it. Lago di Pietrarossa, v nem. besedilu Prerassel (Urbar za Devin 1494, M. Kos, Srednjeveški urbarji za Slovenijo III, str. 207), hdn v občini Tržič/Monfalcone, na meji z občino Doberdob. Danes je Prelosno jezero v območju naravnega rezervata Doberdobskega in Prelosnega jezera.V osrednjem in najglobljem delu voda nikoli ne presahne. Celotno območje je kljub zaščiti znatno spremenjeno, ker je skozi kotlino speljana avtocesta. Moteč je tudi vpliv naftovoda in plinovoda. Še do nedavna pa je bilo na vzpetini nad jezerom veliko vojaško strelišče.

Poleg hidronima Prelosno se občasno uporablja tudi ime Laško jezero. Delno razlago najdemo v Jožefinskem vojaškem zemljevidu, kjer je omenjeno jezero navedeno kot Jesero Veneto, kar bi ustrezalo hidronimu Laško jezero. Navedba vojaških topografov iz druge polovice 18. stoletja je smiselna in razumljiva. Jezero je bilo takrat v celoti na ozemlju Beneške republike in je bilo zato pač Jesero Veneto. Težko pa je odgovoriti na vprašanje, ali so vojaški topografi vpisali ime, ki je bilo že v rabi med krajani, ali pa so, na osnovi neke tudi takrat močno prisotne birokratske miselnosti, jezero poimenovali kar po svoje.

O izvoru in rabi imena Laško se je mogoče poučiti v zborniku Slovenci v Laškem (2005).

Bolj zapletena pa je razlaga nastanka in pomena imena Prelosno (narečno Prielostno) jezero. Maurizio Puntin (Toponomastica storica del Territorio di Monfalcone) navaja (ASCM, 43) citata iz leta 1569 Piera rossa in 1583 Pierarossa, kjer se omenja tudi mlin. Ime Pietrarossa je zabeleženo tudi v Franciscejskem katastru in na mapah katastrske občine Jamlje in katastrske občine Tržič/Monfalcone.

Puntin pojasnjuje nastanek italijanske oblike imena (Pietra rossa) s prisotnostjo državne meje med Beneško republiko in avstrijskimi deželami. Mejo so označevali kamni, ki so bili škrlatnordeče barve in avtor navaja podobno situacijo, prav tako na mejnem območju, v kraju Isola Morosini (občina Škocjan ob Soči/San Canzian d'Isonzo) ter na nekdanji meji med Beneško republiko in deželo Tirolsko.

$\mathrm{V}$ podkrepitev take razlage govori še en podatek, in sicer oronim Cimo di Pietra rossa, ki je zelo verjetno tudi nastal po letu 1420 (ime je navedeno tudi v Franciscejskem katastru).

Ob tem se seveda postavlja vprašanje, odkod slovensko Prelosno, oziroma Prelostno in Prielostno jezero. Gre za domači govorici prilagojeno obliko italijanskega imena Pietra/Pierarossa? ${ }^{1}$

V krstnih knjigah za vikariat Jamlje (do leta 1873 so se vodile v Devinu, potem samostojno), kamor je sodil tudi mlin v Prelosnem, sta zabeleženi obliki, Prelazno (ex Prelazno) in Prelostno.

1 O razlagi imena Prelosno po disimilaciji iz *Preroslo France Bezlaj, Etimološki slovar slovenskega jezika III, 109, sub voce Prẹ́doslje. (Op. ur.) 
Ob upoštevanju dejstva, da gre za področje, kjer so pogosti medsebojni jezikovni vplivi (interference), bi kazalo vzeti v poštev še eno možno razlago. Nad jezerom se namreč dviga (kota 144) kopast vrh, ki je na zemljevidih in mapah označen Arupacupa in ki je bil, po moji oceni, zelo nerodno poslovenjen v Gerupo kopo.

Ni dvoma, da gre za sestavljeno ime in da je drugi del (kopa) pravšnji, saj povsem odraža morfologijo reliefa. Dvom se pojavlja glede prvega dela Arupa/Gerupa. Jameljci uporabljajo za goro ime Vrtače. Wertatschek je zabeleženo na Jožefinskem vojaškem zemljevidu.

Gerup oziroma gherjup v krajevni govorici pomeni zoprn, nesladek, bridek, v prenesenem pomenu, tudi s težavo pridobljen. Kaj pa če je hibridna in težko razumljiva oblika (Arupacupa) samo rezultat netočnega ali površnega zapisa ali prepisa in imamo v osnovi opravka z navadno Ruso kopo? Rús na Primorskem in posebej na Goriškem pomeni rdeč (Pleteršnik). Če poznamo in sprejemamo imeni Rdeči rob in Bele stene, zakaj ne bi sprejeli Ruse kope? Toliko bolj, ker imamo čisto blizu vsaj dva primera sestavljenih oziroma dvodelnih imen. Z Gerupe kope/Ruse kope se nad Doberdobskim jezerom lepo vidi Rúsi škólj, obsežnim, nekdaj srenjskim pašnikom, ki se spuščajo od Doberdoba proti jezeru pa krajani od nekdaj pravijo Črna griža.

DOBERDOBSKO JEZERO, n. s., it. Lago di Doberdò, nem. Doberdoer See (Franciscejski kataster in kasnejši dokumenti). V vseh primerih gre, po vsej verjetnosti, za umetno in iz upravnih potreb oblikovano ime. Krajani, tako v Doberdobu kakor v Jamljah (površina jezera je namreč razdeljena med omenjeni vaški skupnosti, pri čemer je večji del, nekaj nad 20 hektarov, v katastrski občini Doberdob), uporabljajo samo ime Jezero, kar je povsem razumljivo, saj je to edino jezero na njihovem območju, od nekdaj glavni vir pitne vode. Jezero je bilo v preteklosti intenzivno koriščeno, od lova in ribolova do košnje peluda (rogoza). Obsežna površina, ki je danes del naravnega rezervata Doberdobskega in Prelosnega jezera in hidrološke značilnosti - izviri podtalnice so na jugozahodni strani, podzemni odtoki, požiralniki pa na vzhodni (jameljski) strani, povezuje pa jih vijugasta rečica - so prispevale k nastanku niza zanimivih vodnih imen. Glavnemu izviru v jezeru domačini pravijo Grulja, manjšim pa Luknja. Rečica, po kateri voda odteka proti Jamljam, je Močivnica. Manjši kanal (hidrografija se namreč pogosto spreminja) pa je Roja.

V jezerskem dnu so se do danes, kljub različnim poskusom, vrtanjem in sondiranjem (pred desetletji so na območju jezera nameravali graditi raziskovalni center s svetlobnim pospeševalnikom in so v ta namen opravili niz geoloških raziskav in poskusov stabilnosti jezerskega dna) ohranile tri kotanje, bézni, ki so stalno zaliti z vodo (Prvi bézen, Drugi bézen, Treči (Tretji) bézen). Največji in od daleč najbolj opazen je Treči bézen na jameljski strani. Na skrajnem vzhodnem delu jezera je Plutnik. Območje jezera, kjer so še pred nekaj desetletji kosili rogoz, bodisi za nastilj bodisi za pletenje piconov, je Pelud.

Pelúd (ponekod tudi Palud) je fitonim za rogoz. Pomeni pa lahko tudi močvirje, mlakužo, kjer uspeva trsje. Picòni so posebne iz trsja (peluda) pletene mreže za sušenje sadja. Uporabljali so jih tudi pri gojenju sviloprejke. Nekdaj so iz trsja pletli tudi mreže, ki so jih uporabljali v gradbeništvu, za ometavanje lesenih stropov. Ime tako pletene mreže je gržòla. 
Pelúd, picòn in gržòla so izposojenke iz furlanščine: palût, pezzòn (tudi gradiz) ter grisòl (grisòle, grisiòle).

Nejasen je pomen imen Grulja in Plutnik. Možno, vendar ne dovolj prepričljivo razlago za Plutnik najdemo v Pleteršnikovem slovarju, kjer za plutnik navaja, da je to vrsta perunike. Jezero je dejansko zelo zanimivo tudi s florističnega vidika (posebej velja opozoriti na bujno cvetenje poletnega velikega zvončka - Leucojum - ob bregovih) in v okolici rastejo tudi perunike. Ne vidim pa logične povezave, zakaj bi kraški požiralnik poimenovali po rastlini, ki dobro uspeva v skalnatih prisojnih legah.

$\boldsymbol{M O S} \breve{\boldsymbol{C}} \boldsymbol{E} \boldsymbol{N I C A} \boldsymbol{M} \boldsymbol{M O} \check{\boldsymbol{S}} \breve{C} \boldsymbol{E N I C E}$, f. s, f. pl., hdn in tpn na meji med katastrskima občinama Jamlje in Tržič/Monfalcone (danes tudi meji med občinama Doberdob/ Doberdò del Lago in Tržič/Monfalcone). Pavle Merkù (Krajevno imenoslovje na slovenskem zahodu, str.135) navaja imeni Moščénca in Muščénice za mlin in hišno ime. Terenska raziskava opozarja na množinsko obliko toponima (pri Moščenicah). Maurizio Puntin navaja, sklicujoč se na listine iz obdobja beneške uprave, vsekakor po letu 1558, ime Moscheniza, in razlaga, da je ime veljalo za območje bližnjega hriba in tudi potoka. V opisu občinske meje med katastrskima občinama Jamlje in Medja vas (Franciscejski kataster, 1818) zasledimo Mosiniza (isti vir navaja tudi lastnika zemljiške parcele, Pavletiča iz Gabrij), kar se zdi bliže Močivnici (ime roje v bližnjem Doberdobskem jezeru, po kateri se pretaka voda od izvirov na zahodni strani (Grulja) proti požiralnikom na vzhodni strani).

V krstnih knjigah župnije Jamlje je beležka (ex Moščenice, 6), kar navaja k razmišljanju, da se za različnimi oblikami pravzaprav skrivata dve imeni: hidronim Močivnica, potok, ki priteka iz Sabeljskega jezera, in mikrotoponim oziroma toponim Moščenice.

MAUTTA, hdn potoka na meji katastrske občine Rubije in Petovlje. Danes poteka po strugi, ki je običajno suha, ob deževju pa bogata $\mathrm{z}$ vodo, in predstavlja mejo med občinama Sovodnje ob Soči/Savogna d'Isonzo in Zagraj/Sagrado. Ime Mautta je navedeno v Franciscejskem katastru, v opisu meje katastrske občine Rubije (1818) in na opisu priloženi risbi, medtem ko se v kolektivnem spominu ni ohranilo. Potok, ki izvira na majhni planoti pri zaselku Boškini, je za domačine samo Potok.

Skromen podatek, da je nastanek imena mogoče pojasniti z obstojem mitnice, najdemo v razpravi Milka Kosa (Srednjeveški urbarji za Slovenijo III, str. 209). Navedba je sicer precej splošna in omenja samo mitnico v Gabrjah, kar pa ni daleč od Rubij oziroma od potoka Mautte.

Odkod torej ime? Z ozirom na to, da je tod potekala meja med Goriškim in Tržaškim okrožjem in da je ob Vipavi in Soči bila speljana pot med Rubijami, Petovljami in Zagrajem, kjer je bila v bližini tudi državna meja, je bila najbrž tu mitninska postaja. Globoka struga potoka je že sama predstavljala naravno zapreko, ki jo je bilo težko zaobiti. Die Maute v nemščini pomeni mitnino oziroma mitnico. V slovarju Nuovo Pirona (NP) je naveden toponim Mauta v kraju Pravisdomini, v zahodni Furlaniji.

P'Č/POČKA

Apelativ p’̌́, m. s., je iz furlanskega pòc , pòz s pomenom »vodnjak s talno, 
izvirno vodo«. V drugem primeru imamo opravka $\mathrm{z}$ istim apelativom, le da je tu uporabljena manjšalna pripona $-k a$.

$P^{\prime} c ̌$ je splošno znano in razširjeno vodno ime v spodnjem nižinskem delu goriške kotline (Miren, Sovodnje, Rupa, Peč, Gabrje).

$P O C \check{C} A$, f. s., je ime manjšega vodnega vira nad zaselkom Mikoli v Dolu. Za isto, vendar širše območje, je znano tudi ime Dolina pri Kalu. Glede pomena imena $P^{\prime c}$ velja opozoriti na furlanski priimek Pozzâr (kopač vodnjakov) in hišno (domače) ime $P^{\prime c ̌ a r ~ v ~ S o v o d n j a h . ~}$

PÍVKA/PÍUKA, f. s., pri Píu(v)ki, na Píu(v)ki, ime označuje večje območje na dveh prodnatih terasah, na meji med Štandrežem, Sovodnjami in Pečjo. Ime bi lahko uvrstili tudi v kategorijo mikrotoponimov. Na Pivko sem naletel le v arhivskih virih (Franciscejski kataster). Domnevati je mogoče, da je bil na tem mestu požiralnik oziroma močno prepusten prodnat teren, kamor je izginjala voda iz Velikih roj. Podoben geološki pojav je bil v preteklosti med Rupo in Mirnom. V Terezijanskem katastru najdemo toponim Nad beznom. Novejšega nastanka pa je mikrotoponim Velika jama.

\section{ROJA, ROŠTA, REBOK}

To so hidronimi na območju Rubij, Sovodenj, Petovelj, Zdravščin.

$R O J A$, f. s., pomeni umetni kanal, speljan za dovajanje vode na mlinska kolesa (npr. Roja pri Rubijah). V Furlaniji pomeni Roja tudi naravni vodotok. Izvedeno iz furlanskega ròje, ròe.(NP)

$R O S ̌ T A$, f. s., pomeni jez, umetno pregrado v rečni strugi, redkeje se ime uporablja za naravno pregrado. Izvedeno iz furlanskega ròste. (NP).

$R E B O K, \mathrm{~m}$. s., mrtev rokav v rečni strugi, običajno bogat z ribami.

Ime je v rabi v Sovodnjah, Petovljah in Zdravščinah. Izvedeno je iz furlanskega revòc, rivòc $(\mathrm{NP})$.

$\boldsymbol{P O Z ̌ E R L J U ́ H , ~ m . ~ s . , ~ j a m a , ~ p o z ̌ i r a l n i k , ~ o b i c ̌ a j n o ~ v ~ n a j n i z ̌ j e m ~ d e l u ~ k r a s ̌ k e g a ~}$ polja, kamor ob deževju odteka voda. Požerljuh med Vižintini in Palkiščem.

\section{Viri in literatura}

ASCM - Archivio Storico Comune di Monfalcone.

Bezlaj, France, 1956, 1961, Slovenska vodna imena I-II, Ljubljana.

Bezlaj, France, 1976-2005, Etimološki slovar slovenskega jezika I-IV, Ljubljana.

Brecelj, Marijan, 2005, Furlansko-slovenski slovar, Nova Gorica.

Waltritsch, Marko (ur.), 1988, Doberdob včeraj in danes, Doberdob, 1988.

Domini, Silvio, 1998, Staranzano: storia, società e cultura tra Otto a Novecento, Staranzano.

Fajt, Vilko, 2002, Družinska imena v Sovodnjah. Utrinki naše preteklosti, Sovodnje ob Soči.

Franciscejski kataster. Opisi katastrskih občin, lastnikov zemljiških in stavbnih parcel, cenitve in mape. Gradivo v Državnem arhivu v Gorici (Archivio di Stato).

Goriško ozemlje. Zemljevid s krajevnimi in ledinskimi imeni, Trst - Gorica, 1999. 
- Jožefinski kataster. Registri lastnikov in popis parcel. Gradivo v Državnem arhivu $v$ Gorici (Archivio di Stato).

Klemše, Vlado, 1997, S Poklona do Toplice. Krajevna, ledinska, vodna in druga imena v Štmavru, Pevmi in na Oslavju, Štmaver.

Kos, Milko, 1954, Srednjeveški urbarji za Slovenijo III. Urbarji Slovenskega Primorja. Drugi del, Ljubljana.

Krstne knjige. Prepisi krstnih knjig posameznih župnij, v Nadškofijskem arhivu v Gorici.

Martinčič, Andrej, Sušnik, Franc, 1969, Mala flora Slovenije, Ljubljana.

Merkù, Pavle, 2006, Krajevno imenoslovje na slovenskem zahodu, Ljubljana.

Pirona, Giulio Andrea, 1979, Il Nuovo Pirona. Vocabolario friulano, Udine.

Pleteršnik, Maks, 2006, Slovensko-nemški slovar. Transliterirana izdaja, Ljubljana.

PSCC - Provveditori Sopraintendenti alla Camera dei Confini, v Archivio di Stato di Venezia.

Puntin, Maurizio, 2003, Toponomastica storica del Territorio di Monfalcone e del comune moderno di Sagrado, Gradisca d'Isonzo.

Klemše, Vlado (ur.), 2005, Slovenci v Laškem, Tržič.

Slovenija na vojaškem zemljevidu 1763-1787 (1804), 3. zvezek, Ljubljana, 1997.

Snoj, Marko, 1997, Slovenski etimološki slovar, Ljubljana.

Waltritsch, Marko (ur.), 1983, Sovodenjski zbornik, Sovodnje.

Tabor "Doberdob 82". Gradivo mladinskega raziskovalnega tabora, Ljubljana, 1983.

TEA - Thesaurus Ecclesiae Aquileiensis.

Terenska raziskava avtorja.

Terezijanski kataster. Registri lastnikov, kolonov in bremen. Gradivo v Državnem arhivu v Gorici (Archivio di Stato).

Tržaško ozemlje. Zemljevid in seznam ledinskih imen, Ljubljana - Trst, 1978.

\section{Hydronyms in the Doberdo Karst Area}

Summary

Doberdob (the Doberdo) karst area stretches between Štivan (San Giovanni) and the Vipava (Vipacco) River, and between Dol (Vallone) and the Friulian Plain, and is of great toponymic interest. This has been an area of intersection between the Slavic and Romance worlds for centuries. The border between Venice and Austria ran along the karst rim between Soča (the Isonzo) River and Tržič (Monfalcone) for several centuries. As a result, the intertwining of linguistic influence is more present and obvious in this area.

In addition to the special historical features mentioned above, this region is also interesting in another way. The Doberdo karst area is rich and interesting in terms of geomorphology. In a relatively small area, there are four intermittent 
lakes, as well as numerous ponds, sinkholes, distinctly flashy streams, and caves with groundwater.

Water has always been a precious element and an element of survival for people living in the Karst region. This is also reflected in its wealth of hydronyms, the majority of which have been preserved either through oral traditional or archival material.

The author concentrates on the hydronyms associated with Doberdobsko jezero (Lake Doberdo), Prelosno jezero (Lake Pietrarossa), Sabeljsko jezero (the Sablici Marsh), and the Močile (Mucille Lakes). Findings and explanations of the names to date are presented, and attention is drawn to typical hydronyms such as Črepola/Črepolo, P'č, Počka, Rebok, Rošta, Roja, and Pivka.

Vlado Klemše

Case sparse 54, I-34070 Sovodnje/Savogna d'Isonzo (GO) vlado.klemse@virgilio.it 